Article

\title{
Oxidative Chemical Stressors Alter the Physiological State of the Nasal Olfactory Mucosa of Atlantic Salmon
}

\author{
Carlo C. Lazado ${ }^{1, *(1)}$, Vibeke Voldvik ${ }^{1}$, Mette W. Breiland ${ }^{2}$, João Osório ${ }^{1,3}{ }^{(0)}$, \\ Marianne H. S. Hansen ${ }^{1} \mathbb{D}$ and Aleksei Krasnov ${ }^{1}$ \\ 1 Nofima, The Norwegian Institute of Food, Fisheries and Aquaculture Research, 1433 Ås, Norway; \\ vibeke.voldvik@nofima.no (V.V.); joao.osorio96@gmail.com (J.O.); \\ marianne.h.s.hansen@nofima.no (M.H.S.H.); Aleksei.Krasnov@Nofima.no (A.K.) \\ 2 Nofima, The Norwegian Institute of Food, Fisheries and Aquaculture Research, 9019 Tromsø, Norway; \\ Mette.W.Breiland@Nofima.no \\ 3 CIISA, Faculty of Veterinary Medicine, University of Lisbon, 1300-477 Lisbon, Portugal \\ * Correspondence: carlo.lazado@nofima.no
}

Received: 5 September 2020; Accepted: 17 November 2020; Published: 18 November 2020

\begin{abstract}
The olfactory organs of fish have vital functions for chemosensory and defence. Though there have been some ground-breaking discoveries of their involvement in immunity against pathogens in recent years, little is known about how they respond to non-infectious agents, such as exogenous oxidants, which fish encounter regularly. To this end, we employed Atlantic salmon (Salmo salar) as a model to study the molecular responses at the nasal olfactory mucosa of a teleost fish when challenged with oxidants. Microarray analysis was employed to unravel the transcriptional changes at the nasal olfactory mucosa following two types of in vivo exposure to peracetic acid (PAA), a highly potent oxidative agent commonly used in aquaculture: Trial 1: periodic and low dose (1 ppm, every 3 days over 45 days) to simulate a routine disinfection; and Trial 2: less frequent and high dose (10 ppm for $30 \mathrm{~min}$, every 15 days, 3 times) to mimic a bath treatment. Furthermore, leukocytes from the olfactory organ were isolated and exposed to PAA, as well as to hydrogen peroxide $\left(\mathrm{H}_{2} \mathrm{O}_{2}\right)$ and acetic acid (AA) - the two other components of PAA trade products-to perform targeted cellular and molecular response profiling. In the first trial, microarrays identified 32 differentially expressed genes (DEG) after a 45-day oxidant exposure. Erythrocyte-specific genes were overly represented and substantially upregulated following exogenous oxidant exposure. In Trial 2, in which a higher dose was administered, 62 DEGs were identified, over $80 \%$ of which were significantly upregulated after exposure. Genes involved in immune response, redox balance and stress, maintenance of cellular integrity and extracellular matrix were markedly affected by the oxidant. All chemical stimuli (i.e., PAA, $\mathrm{H}_{2} \mathrm{O}_{2}$, AA) significantly affected the proliferation of nasal leukocytes, with indications of recovery observed in PAA- and $\mathrm{H}_{2} \mathrm{O}_{2}$-exposed cells. The migration of nasal leukocytes was promoted by $\mathrm{H}_{2} \mathrm{O}_{2}$, but not much by PAA and AA. The three chemical oxidative stressors triggered oxidative stress in nasal leukocytes as indicated by an increase in the intracellular reactive oxygen species level. This resulted in the mobilisation of antioxidant defences in the nasal leukocytes as shown by the upregulation of crucial genes for this response network. Though qPCR revealed changes in the expression of selected cytokines and heat shock protein genes following in vitro challenge, the responses were stochastic. The results from the study advance our understanding of the role that the nasal olfactory mucosa plays in host defence, particularly towards oxidative chemical stressors.
\end{abstract}

Keywords: fish; mucosal immunity; nasal immunity; oxidative stress; peroxide 


\section{Introduction}

Oxidative stress is a physiological state in an organism in which the redox balance is altered, as characterised by an increase in the levels of reactive oxygen species (ROS) but normal or low amounts of antioxidants, which may be due to compromised neutralisation property and/or scavenging potential $[1,2]$. Fish, like many other organisms, have an extensive repertoire to counteract oxidative stress [2,3]. The integrated antioxidant systems, which include enzymatic and nonenzymatic antioxidants, are at the forefront of blocking the harmful effects of ROS [1]. Redox imbalance associated with oxidative stress promotes genetic instability, changes in gene expression patterns, alterations in cellular signalling cascades/cell metabolism, and disruption of the cell cycle, leading to several pathophysiological conditions $[4,5]$.

Oxidants can be endogenously produced or derived from external sources. Endogenous ROS are produced from molecular oxygen as a result of normal cellular metabolism [1], and ROS are constantly produced in all living cells in which roughly up to $1 \%$ of an animal's total oxygen consumption may be attributed to ROS generation and detoxification [6]. Exogenous ROS may come from various sources, and their impacts on redox status have consequences on cell viability, activation, proliferation, and organ function. Farmed fish encounter an increased flow of exogenous ROS several times during a lifetime, as many husbandry practices employ ROS-generating compounds either as a form of disinfectant or water treatment, or as a chemotherapeutant [7-11]. The antimicrobial activity of ROS towards opportunistic and pathogenic microorganisms underlines their use in providing fish with a favourable rearing environment [12]. Nonetheless, our knowledge of the physiological alterations associated with exogenous ROS, mainly from ROS-generating agents being used in fish farming, is fragmentary.

Mucosal organs of fish are multifunctional; besides their role in defence, they carry a multitude of other physiological functions $[13,14]$. They are often considered the first line of defence because these structures interact with the water matrix where several biological and chemical challenges present themselves regularly. In recent years, there has been a dramatic development in the study of the physiology and immunology of mucosal surfaces in fish, driven mostly by their warranted importance in maintaining the health of farmed fish $[13,15]$.

The nasal olfactory system plays a role not only in chemoreception but also in immune defence, as it is considered an ancient component of the mucosal immune system of vertebrates [16]. It is a highly specialised sensory organ for the detection and identification of minute quantities of chemicals in the environment $[17,18]$, and because water constantly circulates through the nasal cavities, they are continuously prompted with environmental challenges [19]. The mucosal regions of the fish olfactory lamellae have different cellular elements such as goblet cells, sustentacular cells, olfactory sensory neurons, and, most importantly, a rich assemblage of immune cells [19-21]. Vertebrate olfactory sensory neurons rapidly sense chemical stimuli in the environment and transduce signals to the central nervous system [18]. The nasopharynx-associated lymphoid tissue (NALT) protects the teleost olfactory organ from water-borne pathogens, just as for airborne pathogens in terrestrial animals [16]. Several recently published studies have demonstrated how viral and bacterial stimulations affect the immunological repertoire of the nasal mucosa in fish. They reveal a very distinct microenvironment that can mount a localised immunity and, at the same time, influence distant immune functions [14,16,18-20,22]. Non-infectious agents such as exogenous oxidants are delivered via water and are expected to pass through the nasal cavity of fish. In mammalian models, oxidative stressors are highly potent modulators of the nasal epithelium, and the interaction could induce morphological and pathological alterations [23-25]. However, in fish, the influence of exogenous oxidants on the nasal olfactory mucosa is barely explored, despite its common use.

This study explored the impacts of oxidative chemical stressors on the nasal olfactory mucosa of Atlantic salmon (Salmo salar). We employed both in vivo and in vitro strategies to unravel the molecular changes in the nasal olfactory mucosa when challenged with exogenous oxidants relevant in fish farming. In this study, we employed peracetic acid (PAA) as the main oxidant, as it is currently 
being developed as a chemotherapeutant (i.e., for amoebic gill disease-AGD) and disinfectant in recirculating aquaculture systems for salmon $[4,26]$, and the results here are expected to help underline its potential for use. Both in vivo trials were designed to simulate the prospective use of PAA as either a routine disinfectant (Trial 1) or a treatment for a parasitic infection (Trial 2). In addition, in vitro trials were conceived to understand the physiological state of a specific cell type at the mucosa in response to not only PAA but also hydrogen peroxide $\left(\mathrm{H}_{2} \mathrm{O}_{2}\right)$ and acetic acid (AA). These two compounds are present in equilibrium with PAA in its trade product.

\section{Materials and Methods}

\subsection{Oxidant Exposure Experiment}

All fish handling procedures described in this paper followed the Guidelines of the European Union (2010/63/EU) and the in vivo exposure trials received approvals from the Norwegian Food Safety Authority (FOTS, Forsøksdyrforvatningen tilsyns- og søknadssystem IDs 20831, 19321). All key personnel have a FELASA (Federation of European Laboratory Animal Science Associations) $\mathrm{C}$ certificate to conduct experimentation on live animals. Two independent in vivo trials (Figure 1) were performed in which the application of the exogenous oxidant was based on its proposed use for that particular stage of Atlantic salmon production. It was ensured that all fish used in the experiments (both in vivo and in vitro) did not have a history of oxidant exposure. Peracetic acid is available under different trade products and two commercially available PAA-based disinfectants were used in this study. All three major components of PAA trade (i.e., PAA, hydrogen peroxide and acetic acid) products have disinfection power, though PAA is the most potent contributor to the disinfection property of PAA-based disinfectants.

Trial 1 was conducted at Nofima Centre for Recirculation in Aquaculture (NCRA; Sunndalsøra, Norway) and was aimed at evaluating the impacts of periodic low-dose oxidant exposure on the transcriptome of the nasal olfactory mucosa. This experiment was designed to mimic the use of the oxidant as a routine water disinfectant in a recirculating aquaculture system [27]. Briefly, each of the four $3.2 \mathrm{~m}^{3}$ octagonal tanks in a recirculation system was stocked with 735 smolts with an average weight of around $90 \mathrm{~g}$. After four weeks of acclimatisation, the oxidant in the form of a peracetic acid-based disinfectant (Perfectoxid, Novadan ApS, Kolding, Denmark) was directly applied to each tank at a nominal concentration of 1 ppm every 3 days for 45 days, making a total of 15 applications in the duration of the trial. This mode of application was patterned on a previous PAA experiment conducted in rainbow trout, a closely related species of salmon [26]. Moreover, the concentration is within the range safe for use in salmon $[4,28]$. It was ensured that the application of PAA on each occasion was between 0900 and 1000 to avoid temporal effects. The following parameters were maintained during the trial: water flow rate at $100 \mathrm{~L} \mathrm{~min}^{-1}$, salinity at $11.6 \pm 0.5 \%$, temperature at $12.8 \pm 0.6^{\circ} \mathrm{C}$, pH at 7.5, dissolved oxygen $>90 \%$ saturation, photoperiod at $24 \mathrm{~L}: 0 \mathrm{D}$, and a continuous feeding regime (Nutra Olympic 3 mm, Skretting, Averøy, Norway).

Trial 2 was performed at Havbruksstasjonen i Tromsø (HiT; Tromsø, Norway) and was designed to unravel the changes in the nasal transcriptome after repeated but less frequent exposure to higher doses of oxidant. PAA is currently being explored as a potential treatment for amoebic gill disease (AGD), a gill health issue affecting mostly seawater-adapted salmon [4,7]. The trial was designed to simulate an oxidant exposure as a treatment protocol for AGD [26]. Forty fish with an average weight of 80-90 g were stocked into a $500 \mathrm{~L}$ circular tank in a flow-through system. There were six tanks in total: three for the control group and three for the oxidant-exposed group. Fish were allowed to acclimatise for a week before the first oxidant treatment was performed. Fish were fasted for $24 \mathrm{~h}$ prior to each treatment occasion. Oxidant treatment was performed as follows: Water flow in the tank was stopped. Thereafter, the oxidant (Divosan Forte ${ }^{\mathrm{TM}}$, Lilleborg AS, Olso, Norway) was added to the water column to achieve a final concentration of $10 \mathrm{ppm}$. This concentration was $2 \mathrm{x}$ higher than the concentration we earlier tested and reported [4]. Aeration was supplied to enable mixing 
and to maintain the oxygen level. After $30 \mathrm{~min}$, the water flow was opened, and over $90 \%$ of the water was replaced within $10 \mathrm{~min}$. Feeding was continued a day after the exposure. This exposure protocol was performed every 15 days and there were three exposure occasions in the whole trial. The following parameters were maintained during the trial: water flow rate at 6-7 $\mathrm{L} \mathrm{min}^{-1}$, salinity at $35 \%$, temperature at $12.0 \pm 1{ }^{\circ} \mathrm{C}$, dissolved oxygen $>90 \%$ saturation, photoperiod at $24 \mathrm{~L}: 0 \mathrm{D}$, and a continuous feeding regime (Nutra Olympic 3 mm, Skretting, Averøy, Norway).
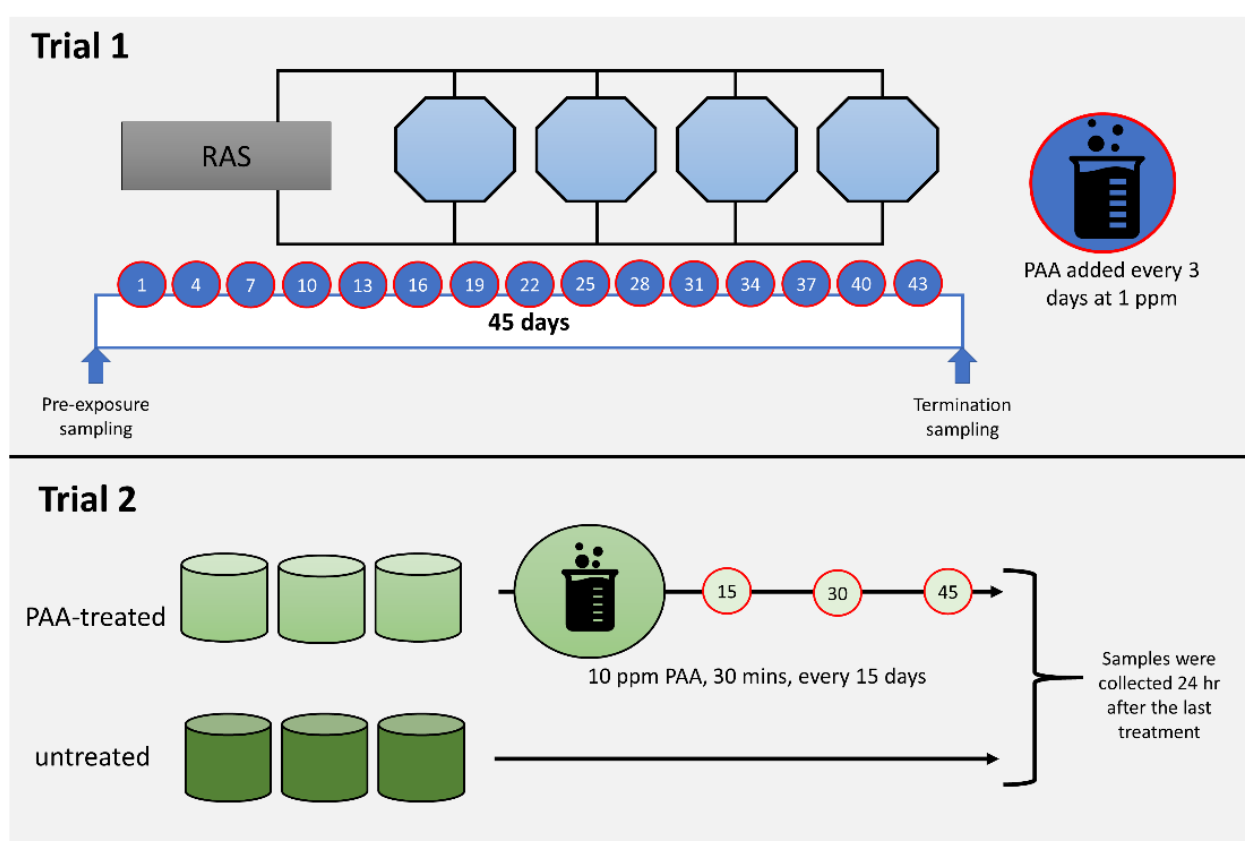

Figure 1. Diagrammatic summary of the in vivo trials. Trial 1 aimed to profile the impacts of periodic and low dose peracetic acid (PAA) application (1 ppm, every 3 days over 45 days), while Trial 2 was designed to investigate the nasal responses following less frequent and high dose PAA treatment (10 ppm for $30 \mathrm{~min}$, every 15 days, 3 times). Details of each trial are described in Section 2.1.

\subsection{Olfactory Organ Collection}

All fish for sampling were humanely euthanised with an overdose of either Tricaine methanesulfonate (Trial 1; MS222, PHARMAQ Ltd., Ås, Norway) or Benzocaine (Trial 2; Benzoak ${ }^{\circledR}$, ACD Pharmaceuticals AS, Oslo, Norway). Percussive stunning was avoided because it triggered the influx of blood to the head, including the olfactory epithelium. Olfactory organ was collected by opening the nostrils to expose the outermost section of the nasal mucosa. The rosette from the left side was then dissected out, immediately suspended in RNAlater ${ }^{\mathrm{TM}}$ (Thermo Fisher Scientific, Sacramento, CA, USA), kept at room temperature overnight for penetration, and then stored at $-70^{\circ} \mathrm{C}$ until RNA isolation. In Trial 1, olfactory rosettes ( $n=8$ per time-point) were collected before and 45 days (i.e., $24 \mathrm{~h}$ after the last PAA application) after the start of periodic oxidant exposure. In Trial 2, the tissue samples $(n=9$, per group) were collected $24 \mathrm{~h}$ after the 3 rd exposure.

\subsection{Isolation of Leukocytes from Olfactory Organ}

Leukocytes from olfactory organ were isolated from 15 freshwater-adapted salmon (ca. 80-90 g) with similar genetic background, following a previously published method [22], with slight modifications. Briefly, fish were humanely euthanised with an anaesthetic overdose (Aqui-S, MSD Animal Health, Drammen, Norway). The olfactory organs from both sides were dissected and immediately placed in a modified L-15 (supplemented with 5\% foetal bovine serum, $1 \%$ Penstrep, 1\% HEPES, 4-(2-hydroxyethyl)-1-piperazineethanesulfonic acid) on ice. Rosettes from all fish were combined, and the tissues were cut into small pieces $(0.5-1 \mathrm{~cm})$ and mechanically dissociated by 
incubating the tissue suspension at $4^{\circ} \mathrm{C}$ for $30 \mathrm{~min}$ with constant agitation. The cell supernatant was collected and temporarily stored at $4{ }^{\circ} \mathrm{C}$. The remaining tissue fragments were suspended in modified L-15 medium and the process of mechanical dissociation was repeated four times. The collected supernatant from the four recurrences was combined and stored at $4{ }^{\circ} \mathrm{C}$. The remaining tissue fragments were suspended in phosphate-buffered saline (PBS) with EDTA (1 mM) and DTT (0.9 mM) and incubated at $4{ }^{\circ} \mathrm{C}$ for $30 \mathrm{~min}$ with constant gentle agitation. The PBS supernatant was thereafter discarded. Enzymatic digestion was carried out by incubating the remaining fragments in collagenase solution $\left(0.15 \mathrm{mg} / \mathrm{mL}\right.$ in L-15, with $1 \%$ Penstrep) for $2 \mathrm{~h}$ at room temperature $\left(20^{\circ} \mathrm{C}\right)$ with agitation. The supernatants from mechanical dissociations and enzymatic digestion were combined, gently passed through a $100 \mu \mathrm{m}$ filter, and spun down at 300× $\mathrm{g}$ for $10 \mathrm{~min}$. The cell pellet was washed and resuspended in modified L-15, laid over a 34\%/51\% isotonic Percoll ${ }^{\circledR}$ (Sigma-Aldrich, Oslo, Norway) gradient. The tubes were then centrifuged for $30 \mathrm{~min}$ at $400 \times \mathrm{g}$ at $4{ }^{\circ} \mathrm{C}$. The cell layer between the gradients was carefully transferred to a tube with modified L-15 medium, centrifuged for 10 min at $400 \times g$ at $4{ }^{\circ} \mathrm{C}$, and suspended in new modified L-15 medium. Cell viability and number were determined by CellCountess ${ }^{\mathrm{TM}}$ II (Thermo Fisher Scientific, Boston, MA, USA). The cells were seeded out onto a 12-well plate (Corning ${ }^{\circledR}$ CellBIND ${ }^{\circledR}$ Surface, Sigma-Aldrich, Oslo, Norway) at a density of $2 \times 10^{5}$ cells per well and incubated at $13{ }^{\circ} \mathrm{C}$.

\subsection{In Vitro Exposure Trial}

The cells were allowed to adhere for $48 \mathrm{~h}$ before the exposure was performed. The leukocytes were exposed to three chemical stressors at physiological concentrations-100 $\mu \mathrm{M} \mathrm{PAA,} 100 \mu \mathrm{M} \mathrm{H}_{2} \mathrm{O}_{2}$, and $100 \mu \mathrm{M} \mathrm{AA}$ - for $30 \mathrm{~min}$. The concentrations were based on several preliminary in vitro trials and the concentrations were selected because they were able to trigger significant increase in intracellular ROS, thereby providing an indication that the internal redox balance had been altered by the tested oxidants. Each treatment group had four independent wells. Untreated cells served as controls and were handled similarly to the treatment groups, though no chemical stressor was added. After $30 \mathrm{~min}$, the media were removed, cells were washed gently with modified L-15, and $300 \mu \mathrm{L}$ of the same media was added to each well. After $24 \mathrm{~h}$, the media were removed. The cells were suspended in lysis buffer (ZYMO Quick-RNA ${ }^{\mathrm{TM}}$ Microprep kit, Sacramento, CA, USA) and scraped, and the cell suspension was stored at $70{ }^{\circ} \mathrm{C}$ until RNA isolation.

\subsection{Proliferation and Migration Assays}

Nasal leukocytes were isolated from 12 freshwater-adapted salmon (ca. 80-90 g) following the method described in Section 2.3 and seeded onto a 96-well plate (Corning ${ }^{\circledR}$, CellBIND ${ }^{\circledR}$ Surface, Sigma-Aldrich, Oslo, Norway) at a density of $10^{5}$ cells per well. After the cells were allowed to settle and adhere for $24 \mathrm{~h}$, they were exposed to PAA, $\mathrm{H}_{2} \mathrm{O}_{2}$, and AA at a physiological concentration of $100 \mu \mathrm{M}$ for $30 \mathrm{~min}$ and washed. New media were added and the exposed cells were allowed to recover in the incubator. Unexposed cells, serving as controls, were likewise washed, and new media were added. Cell proliferation (proxy for cytotoxicity) was measured using the CyQUANT Direct Proliferation Assay (Thermo Fisher Scientific, Boston, MA, USA) 24 and $48 \mathrm{~h}$ after the challenge. Each treatment group, including the unexposed control group, had six replicate wells. Rate of proliferation was expressed relative to the control group of that time-point.

The effects of the chemical stressors on cellular migration were determined by the CytoSelect ${ }^{\mathrm{TM}}$ Cell Migration Assay kit (Cell Biolabs, Inc., Sacramento, CA, USA). Freshly isolated nasal leukocytes were suspended in modified L-15 medium without serum. The lower receptacle of the migration chamber was added with L-15 media containing either PAA, $\mathrm{H}_{2} \mathrm{O}_{2}$, or AA in a final concentration of $100 \mu \mathrm{M}$. Wells with L-15 medium containing 10\% FBS served as the positive control for chemotaxis while L-15 medium alone was designated as a negative control. Each treatment, including the controls, had been assigned three wells. Thereafter, the cells were added to the upper receptacle of the migration chamber at a density of $2 \times 10^{5}$ cells. The migration chamber was incubated for $24 \mathrm{~h}$ at $13{ }^{\circ} \mathrm{C}$ before 
the migratory cells were dislodged from the membrane, lysed and labelled with CyQuant ${ }^{\circledR}$ GR dye solution (Sacramento, CA, USA), and fluorescence was read at $480 \mathrm{~nm} / 520 \mathrm{~nm}$.

\subsection{Intracellular ROS Quantification}

Nasal leukocytes were isolated, cultured, and treated with the chemical stressors as described in detail in Sections 2.4 and 2.5. The intracellular level of reactive oxygen species (ROS) in the treated cells, including untreated control, was quantified using the OxiSelect ${ }^{\mathrm{TM}}$ Intracellular ROS Assay Kit (Cell Biolabs, Inc., San Diego, CA, USA) at 24 and $48 \mathrm{~h}$ after challenge. The level of ROS is given as a proportion of fluorescent dichlorodihydrofluorescein (DCF).

\subsection{RNA Isolation, cDNA Synthesis, and Quantitative Real-Time PCR}

The RNA from both olfactory tissues and nasal leukocytes were isolated using Quick-RNA ${ }^{\mathrm{TM}}$ Microprep kit (Zymo Research, CA, USA). RNA concentration was measured in a NanoDrop 1000 Spectrophotometer (Thermo Fisher Scientific, DE, USA), and the quality of the samples for microarray was further assessed using an Agilent ${ }^{\circledR} 2100$ Bioanalyzer ${ }^{\text {TM }}$ RNA 6000 Nano kit (Agilent Technology Inc., Santa Clara, CA, USA). All samples had an RNA Integrity Value higher than 8.8.

A High Capacity RNA-to-cDNA Reverse Transcription kit (Applied Biosystems, Sacramento, CA, USA) was used to prepare the complementary DNA from the nasal leukocyte samples using 300 ng RNA input following a synthesis protocol of $25^{\circ} \mathrm{C}$ for $10 \mathrm{~min}$, followed by $37^{\circ} \mathrm{C}$ for $120 \mathrm{~min}$ and then $5 \mathrm{~min}$ at $85^{\circ} \mathrm{C}$. The expression of selected antioxidant defence, cytokines, and heat shock protein genes (Supplementary File 1) was quantified using the PowerU ${ }^{\mathrm{TM}}$ SYBR ${ }^{\mathrm{TM}}$ Green master chemistry (Applied Biosystems, Sacramento, CA, USA) in a QuantStudio5 real-time quantitative PCR system (Applied Biosystems, Sacramento, CA, USA). The qPCR reaction mixture included $4 \mu \mathrm{L}$ of diluted cDNA, $5 \mu \mathrm{L}$ SYBR $^{\mathrm{TM}}$ Green Master (Thermo Fisher Scientific, Boston, MA, USA), and $1 \mu \mathrm{L}$ of the forward and reverse primer. All samples were run in duplicate, including minus reverse transcriptase and no template controls. The thermocycling protocol included pre-incubation at $95^{\circ} \mathrm{C}$ for $2 \mathrm{~min}$, amplification with 40 cycles at $95^{\circ} \mathrm{C}$ for $1 \mathrm{~s}$ and at $60^{\circ} \mathrm{C}$ for $30 \mathrm{~s}$, and a dissociation step series of $95^{\circ} \mathrm{C}$ for $15 \mathrm{~s}, 60^{\circ} \mathrm{C}$ for $1 \mathrm{~min}$, and $95^{\circ} \mathrm{C}$ for $15 \mathrm{~s}$. Amplification efficiency was calculated from a five-point standard curve of 2-fold dilution series of pooled cDNA. The expression of the target genes was normalised using three reference genes, namely elongation factor $1 a$ (eef1a), acidic ribosomal protein (arp), and $\beta$-actin (actb) [29].

\subsection{Microarray Analysis}

Olfactory rosettes from Trials 1 and 2 were subjected to microarray analysis using Nofima's Atlantic salmon DNA oligonucleotide microarray SIQ-6 (custom design, GPL16555, Sacramento, CA, USA), which contains $15 \mathrm{~K}$ probes for protein-coding genes involved in immunity, tissue structure, integrity and functions, cell communication and junctions, and extracellular matrix, amongst many others [30]. Agilent Technologies manufactured and supplied the microarrays, reagents, and equipment used in the analysis. Using $110 \mathrm{ng}$ of total RNA template per reaction, RNA was amplified using a One-Color Quick Amp Labeling Kit, and thereafter Cy3 was labelled. Subsequently, fragmentation of the labelled RNA was carried out using a Gene Expression Hybridization Kit and hybridisation followed in an oven thermostatted at $65^{\circ} \mathrm{C}$ with a constant rotation speed of $10 \mathrm{rpm}$ for $17 \mathrm{~h}$. The arrays were washed in sequence with Gene Expression Wash Buffers 1 and 2 and were scanned through an Agilent SureScan Microarray scanner. Data processing was carried out in Nofima's bioinformatics package STARS.

\subsection{Data Handling and Statistics}

The significant difference in the transcript level of the target marker genes between before and after periodic oxidant exposure in Trial 1 and between the unexposed-control and oxidant-exposed groups in Trial 2 was determined by Student's t-test for independent samples; the threshold of differential expression in microarray analyses was 1.75 -fold. The level of significance was set at $5 \%(p<0.05)$. 
A Shapiro-Wilk test was used to evaluate the normal distribution and a Brown-Forsyth test to check for equal variance of the proliferation assay and gene expression data set. Two-way ANOVA was then employed to investigate significant differences amongst treatment groups over time. In addition, the Holm-Sidak test was used to identify pairwise differences. One-way ANOVA was used for migration assay data. All statistical tests were performed using SigmaPlot 14.0 Statistical Software (Systat Software Inc., London, UK), with a level of significance set at $p<0.05$.

\section{Results}

\subsection{Transcriptomic Changes in the Olfactory Rosettes from Trial 1}

After 45 days of periodic low-dose oxidant exposure, microarray analysis identified 32 differentially regulated genes (DEG) in the nasal olfactory rosette (Table 1, Supplementary File 2). The numbers of upregulated (16/32) and downregulated genes were equal (16/32). Erythrocyte-specific genes were the most represented group, with nine transcripts/variants identified as being upregulated in response to the exogenous oxidant. Genes involved in immune response such as c-c motif chemokine 28, interleukin 13 receptor alpha-2, defensin beta 4, ig heavy chain, and mannose-specific lectin-like, were all downregulated after 45 days of oxidant exposure. Two genes encoding cytokeratins were downregulated. Three out of four genes with metabolic functions were likewise downregulated.

Table 1. Some of the differentially expressed genes in the olfactory rosette of salmon from Trial 1. Transcripts are annotated for their known or predicted function. Expression data are ratios of means of 45 days after the exposure to pre-exposure.

\begin{tabular}{ccc}
\hline Annotation & Name & Fold \\
\hline Cytoskeleton & Keratin, type I cytoskeletal 20 & -2.69 \\
Cytoskeleton & Keratin, type I cytoskeletal & -3.16 \\
DNA replication & DNA replication licensing factor MCM6 & 2.34 \\
Chemokine & C-C motif chemokine 28 & -4.33 \\
Cytokine receptor & Interleukin 13 receptor alpha-2 & -1.83 \\
Antibacterial & Defensin beta 4 & -2.60 \\
B cell & Ig heavy chain & -3.69 \\
Lectin & Mannose-specific lectin-like & -2.20 \\
Lipid metabolism & Phosphoethanolamine/phosphocholine phosphatase & -2.43 \\
Protease & Duodenase-1 & -2.20 \\
Protease & Serine protease 23-like & 1.76 \\
Energy metabolism & Pyruvate dehydrogenase kinase isozyme 2 & -2.12 \\
Tissue ECM mucus & Mucin-2 & 2.14 \\
Erythrocyte & Hemoglobin subunit beta-1 & 2.58 \\
Erythrocyte & Hemoglobin subunit alpha (5) & 2.80 \\
Erythrocyte & Hemoglobin subunit alpha-4-like (2) & 5.40 \\
Erythrocyte & Hemoglobin subunit beta & 1.76 \\
\hline
\end{tabular}

For genes with several variants (number enclosed in parentheses), mean values are presented. NB: The complete list of differentially expressed genes (DEGs) is given in Supplementary File 2.

\subsection{Transcriptomic Changes in the Olfactory Rosettes from Trial 2}

Sixty-two DEGs were identified in the olfactory rosettes from fish exposed to an oxidant on three occasions, 56 of which, accounting for $82 \%$ of the DEGs, were upregulated (Table 2, Supplementary File 2). From this group, genes related to immunity, including cytokines and effectors, were largely represented with 14 upregulated transcripts. Genes with innate immune functions constitute a considerable number in the DEG panel. Genes with known involvement in cellular structural integrity such as keratin and plekstrin were likewise upregulated. A similar effect was observed on genes encoding extracellular proteins (e.g., fibronectin, mucin $5 b$ ). Several genes involved in various metabolic pathways were represented in the DEGs panel, such as those involved in amine, amino acid, calcium, and xenobiotic metabolism. A total of 3/4 DEGs of lipid metabolism were downregulated following oxidant exposure. 
Exogenous oxidant exposure upregulated the expression of genes with function in cellular processes such as DNA replication, signalling, and protein folding/modification including the heat shock proteins. Oxidant-induced changes in cellular redox balance were likewise manifested with two DEGs.

Table 2. Some of the differentially expressed genes in the olfactory rosette of salmon from Trial 2 are annotated for their known or predicted function. Expression data are ratios of means of the $10 \mathrm{ppm}$ PAA-treated group to the unexposed/control treated group. Samples were collected $24 \mathrm{~h}$ after the 3rd exposure.

\begin{tabular}{|c|c|c|}
\hline Annotation & Name & Fold \\
\hline Cytoskeleton & Keratin 14 & 1.83 \\
\hline Cytoskeleton & Keratin 4 & 2.05 \\
\hline Cytoskeleton & Keratin cytoskeletal 17 & 3.48 \\
\hline Cytoskeleton & Pleckstrin 2 & 2.11 \\
\hline DNA replication & DNA replication licensing factor MCM6 & 1.75 \\
\hline Protein folding & 14-3-3 protein alpha & 1.82 \\
\hline Protein folding & Heat shock cognate 70 (2) & 3.63 \\
\hline Protein folding & Heat shock protein 90, alpha (2) & 3.53 \\
\hline Signaling & Guanine nucleotide binding protein & 2.06 \\
\hline Redox homeostasis & Glutathione reductase, mitochondrial & 2.26 \\
\hline Redox homeostasis & Redox-regulatory protein FAM213A & -2.67 \\
\hline Signaling & Tyrosine phosphatase type IVA, member 1 (2) & 1.97 \\
\hline Cell Surface & Vacuole membrane protein 1 & 2.12 \\
\hline B cell & IgH-locus & 1.90 \\
\hline Cytokine receptor & Interferon-alpha/beta receptor alpha chain & 1.93 \\
\hline Cytokine receptor & Interleukin 13 receptor alpha-2 & 1.96 \\
\hline Cytokine receptor & Interleukin-1 receptor type II (2) & 2.37 \\
\hline Effector & Differentially regulated trout protein 1 & 2.85 \\
\hline Effector & Ornithine decarboxylase (3) & 2.28 \\
\hline Effector & Thrombin-like enzyme cerastocytin & 2.85 \\
\hline Lymphocyte & T-lymphocite maturation associated protein & 2.72 \\
\hline $\mathrm{T}$ cell & CD276 antigen-like & 2.66 \\
\hline TNF & TNF decoy receptor & 1.90 \\
\hline Effector & Spermidine/spermine N1-acetyltransferase 1 & 4.07 \\
\hline Amino acid metabolism & Methionine adenosyltransferase II, alpha $b$ & 1.97 \\
\hline Calcium metabolism & Protein $S 100-A 1$ & 2.22 \\
\hline Iron metabolism & Ferritin, heavy polypeptide $1 b$ (5) & 2.34 \\
\hline Lipid metabolism & Mid1-interacting protein 1-like & -1.93 \\
\hline Lipid metabolism & Phospholipid transfer protein & -1.92 \\
\hline Lipid metabolism & Short-chain dehydrogenase/reductase 3 & -2.18 \\
\hline Mitochondria & Malic enzyme 3, NADP & -1.87 \\
\hline Protease & Calpain 9(2) & 2.24 \\
\hline Steroid metabolism & Cholesterol 25-hydroxylase-like protein A & 1.92 \\
\hline Sugar metabolism & Glycogen debranching enzyme & -1.90 \\
\hline Xenobiotic metabolism & Glutathione S-transferase P-like & 2.44 \\
\hline Tissue ECM & Fibronection & 1.74 \\
\hline Collagen & Collagen alpha-2(VI) chain & -3.01 \\
\hline Mucus & GMP Giant mucus protein & 1.85 \\
\hline Mucus & Mucin-5B (2) & 1.91 \\
\hline Mucus & Arylalkylamine $N$-acetyltransferase & -1.92 \\
\hline Epithelium & Epithelial membrane protein 2-like & 1.75 \\
\hline Secretory & Gastrotropin-like & 2.83 \\
\hline Lipid metabolism & Globoside alpha-1,3-N-acetylgalactosaminyltransferase 1-like & 2.62 \\
\hline
\end{tabular}

For genes with several variants (number enclosed in parentheses), mean values are presented. NB: The complete list of DEGs is given in Supplementary File 2. 


\subsection{Effects of Oxidative Chemical Stressors on Leukocyte Proliferation and Migration}

The proliferation of nasal leukocytes $24 \mathrm{~h}$ after the challenge was significantly affected by PAA, as well as by its two main components, $\mathrm{H}_{2} \mathrm{O}_{2}$ and AA (Figure 2A). Cellular proliferation reduced by at least 0.5 -fold in all treatment groups and no inter-treatment differences were observed. After $48 \mathrm{~h}$, nasal leukocytes exposed to PAA and $\mathrm{H}_{2} \mathrm{O}_{2}$ slightly recovered, and the proliferation rate did not significantly differ from that of the control group. However, the effect of AA on proliferation was still persistent after $48 \mathrm{~h}$, when the proliferation index in the group was 0.6-fold lower compared to control. Moreover, a significant difference was observed between the AA-exposed and two other treatment groups.

PAA and AA did not significantly affect the migration potential of the nasal leukocytes (Figure 2B). On the other hand, $\mathrm{H}_{2} \mathrm{O}_{2}$ promoted the migration of nasal leukocytes with a significant increase compared to control. A comparison of treatments revealed that $\mathrm{H}_{2} \mathrm{O}_{2}$-induced migration was significantly different from PAA but not from AA.
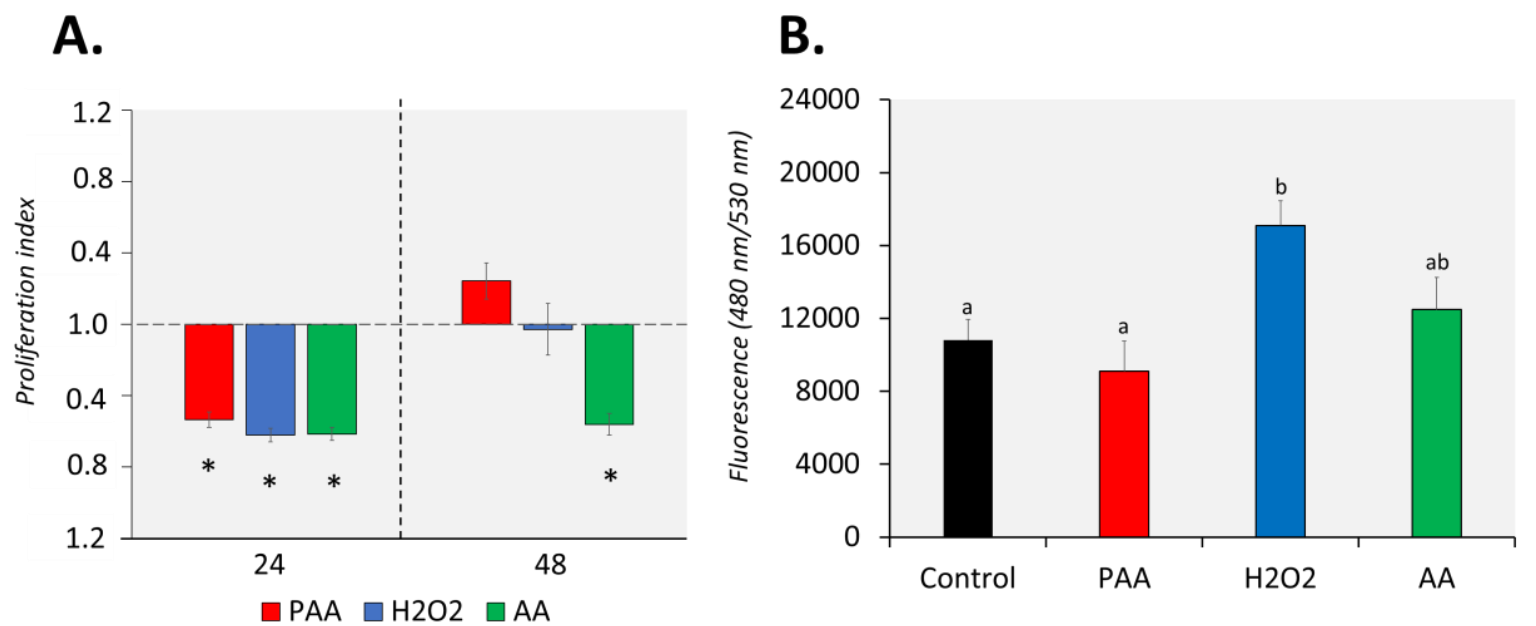

Figure 2. Effects of oxidative chemical stressors on the (A) proliferation and (B) migration of nasal olfactory leukocytes. For the proliferation assay, cells were isolated and cultured for 2 days before they were treated with $100 \mu \mathrm{M}$ of PAA (peracetic acid), hydrogen peroxide $\left(\mathrm{H}_{2} \mathrm{O}_{2}\right)$, and acetic acid (AA) for $30 \mathrm{~min}$. Proliferation was quantified 24 and $48 \mathrm{~h}$ after challenge. Asterisk $\left(^{*}\right)$ denotes that proliferation was significantly affected relative to the unstimulated group. Results are presented as index of proliferation, where we expressed the proliferation relative to the control, unstimulated group. Two-way ANOVA followed by the Holm-Sidak test identified statistical difference amongst treatment groups over time. For migration assay, cells were allowed to migrate to a chamber containing the chemical stressor at a $100 \mu \mathrm{M}$ concentration for $24 \mathrm{~h}$. The positive control group has foetal bovine serum (FBS) as a chemoattractant. One-way ANOVA was used for migration assay data. Different letters a,b indicate significant difference at $p<0.05$. Results are presented as mean \pm SD of 5 (proliferation) $/ 3$ (migration) wells, with cells from 12 fish.

\subsection{Level of ROS in Chemically Stressed Cells}

The three chemical stressors significantly increased the intracellular ROS level of nasal olfactory leukocytes $24 \mathrm{~h}$ after challenge (Figure 3). The highest increment was identified in $\mathrm{H}_{2} \mathrm{O}_{2}$-exposed cells, followed by PAA and AA. In addition, the intracellular ROS of PAA- and $\mathrm{H}_{2} \mathrm{O}_{2}$-exposed cells were significantly higher than in the AA-exposed group at this time-point. After $48 \mathrm{~h}$, the ROS level in PAA and AA-exposed cells displayed no significant difference from the control. The intracellular ROS in $\mathrm{H}_{2} \mathrm{O}_{2}$-exposed cells remained elevated $48 \mathrm{~h}$ after challenge. Moreover, the level was significantly higher compared to the control and AA-exposed cells but not to the PAA-exposed cells. Though not statistically significant, the level in PAA- and $\mathrm{H}_{2} \mathrm{O}_{2}$-exposed cells was apparently lower than the measured level at $24 \mathrm{~h}$ post-challenge. 


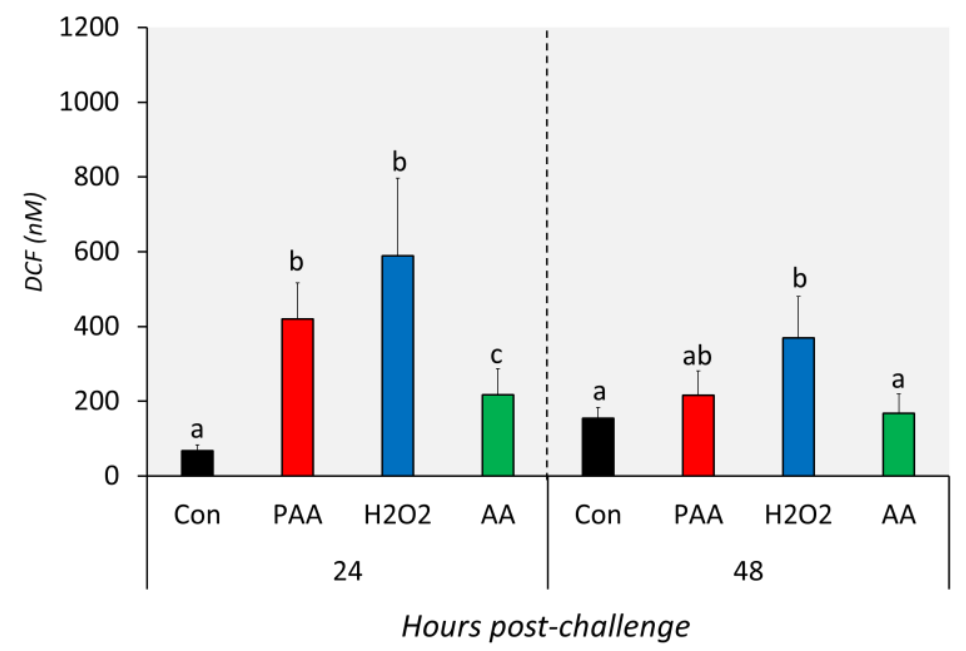

Figure 3. Levels of intracellular reactive oxygen species in nasal olfactory leukocytes exposed to different oxidative chemical stressors. The level was measured at 24 and $48 \mathrm{~h}$ after exposure to $100 \mu \mathrm{M}$ of PAA (peracetic acid), $\mathrm{H}_{2} \mathrm{O}_{2}$, and AA (acetic acid) for $30 \mathrm{~min}$. The control group was handled similarly, but without any chemical stimulation. Two-way ANOVA followed by the Holm-Sidak test identified statistical difference amongst the treatment groups over time. Different letters $a, b$ indicate a significant difference at $p<0.05$ between groups within a time-point. There was no time-related difference within a treatment group. Results are presented as mean \pm SD of 5 wells, with cells from 12 fish.

\subsection{Changes in the Expression of Antioxidant Defence Genes in the Nasal Olfactory Leukocytes}

The expression of six genes with known function in antioxidant defence was differentially affected by the three chemical stressors (Figure 4). The transcript level of gpx was significantly higher in PAA- and $\mathrm{H}_{2} \mathrm{O}_{2}$-exposed cells compared to control at both time-points (Figure 4A). Such an increase was only identified in AA-exposed cells $48 \mathrm{~h}$ after challenge and the expression was significantly higher than the level at $24 \mathrm{~h}$ post-challenge. Chemically induced stress resulted in quite the opposite temporal expression profiles for $g r$ and $g s t a$. An elevated level of $g r$ transcripts was observed in PAA- and $\mathrm{H}_{2} \mathrm{O}_{2}$-exposed groups at $24 \mathrm{~h}$ post-challenge while gsta expression was significantly altered after $48 \mathrm{~h}$ (Figure $4 \mathrm{~B}, \mathrm{C}$ ). In both cases, the expression relative to the other time-point was significantly higher. The transcription of both genes in AA-exposed cells remained unaltered at both time-points. Cat expression was significantly upregulated in $\mathrm{H}_{2} \mathrm{O}_{2}$-exposed cells at both time-points, whereas for the PAA-exposed group, a significant increase was observed only $48 \mathrm{~h}$ post-challenge (Figure $4 \mathrm{D}$ ). There was also a significant difference in cat expression in the PAA-exposed group between the two time-points. AA did not elicit a significant transcriptional change from cat. $\mathrm{Cu} / \mathrm{zn}$ sod was significantly downregulated in the AA-exposed group as compared to control at $24 \mathrm{~h}$, but not at $48 \mathrm{~h}$ after challenge. While $c u / z n$ sod expression was unaltered in the PAA-exposed group at both time-points, a significant increase was observed in the $\mathrm{H}_{2} \mathrm{O}_{2}$-exposed group but only after $48 \mathrm{~h}$. C Cu/zn sod expression in $\mathrm{H}_{2} \mathrm{O}_{2}$-exposed cells at $24 \mathrm{~h}$ was likewise higher compared to the level at $48 \mathrm{~h}$. The overall expression of mnsod displayed no significant alterations, except in PAA-exposed cells $48 \mathrm{~h}$ after challenge, where the expression was at least three times higher than the control and other treatment groups. 
A.

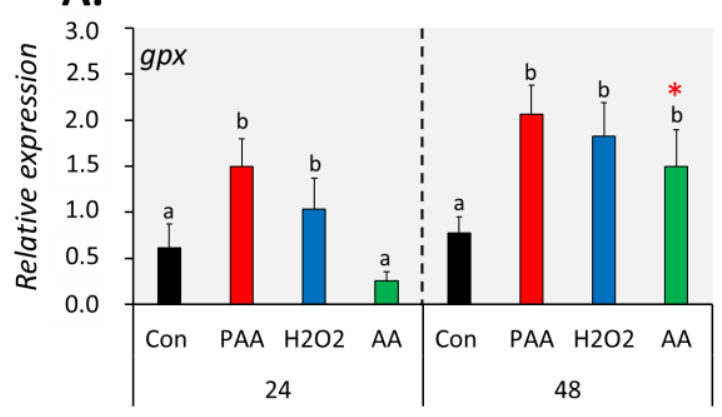

B.

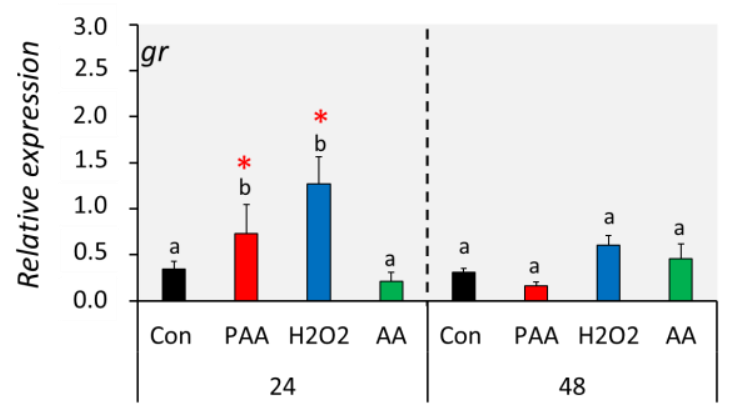

C.

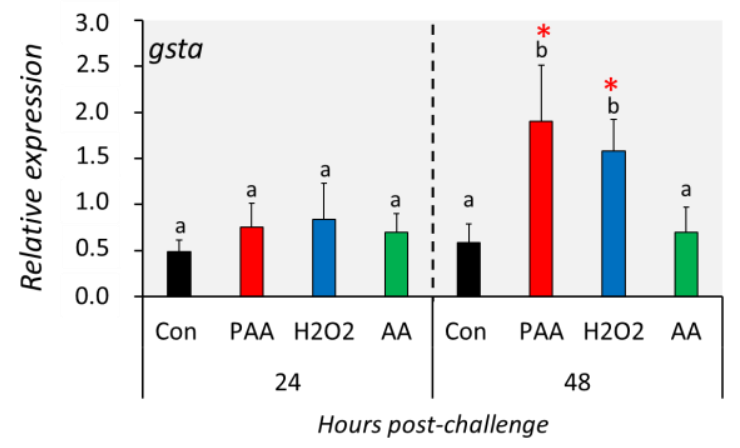

D.

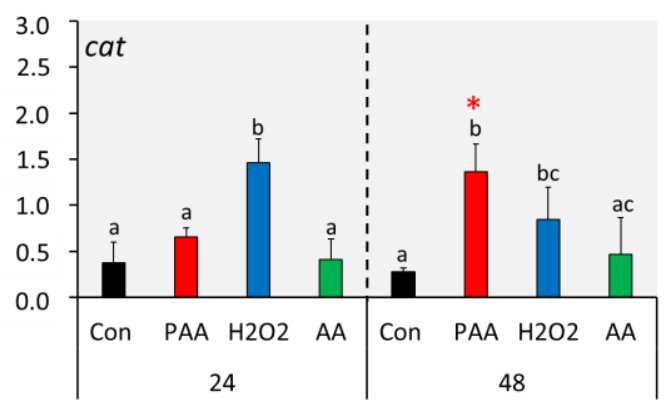

E.

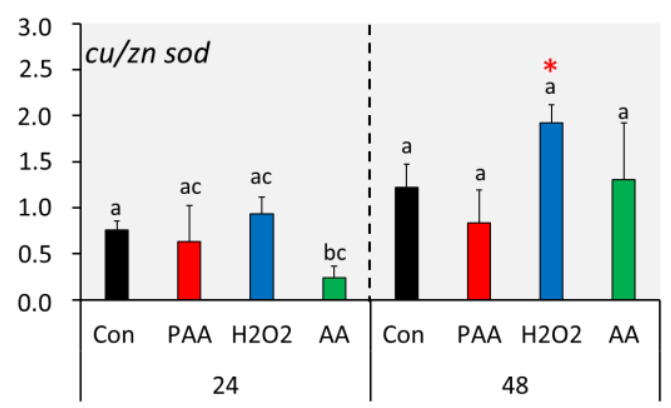

F.

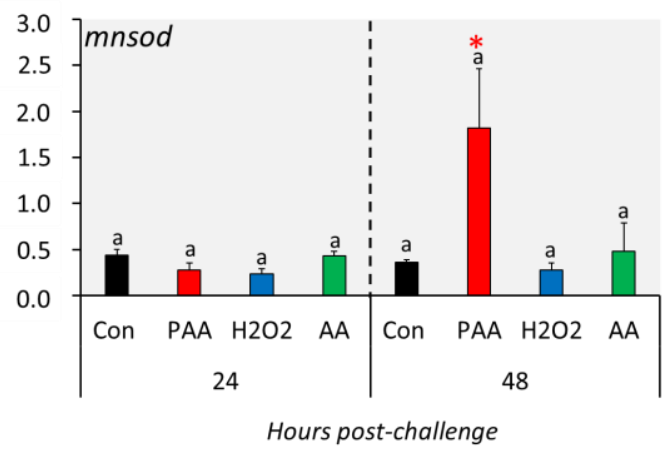

Figure 4. Changes in the expression of antioxidant defence genes following exposure to oxidative chemical stressors (A-F). The transcript level of six selected genes (i.e., gpx, gr, gsta, cat, cu/zn sod, mnsod) was quantified by RT-qPCR at 24 and $48 \mathrm{~h}$ after exposure to $100 \mu \mathrm{M}$ of PAA, $\mathrm{H}_{2} \mathrm{O}_{2}$, and AA for $30 \mathrm{~min}$. The control group was handled similarly, but without any chemical stimulation. Two-way ANOVA followed by the Holm-Sidak test identified statistical difference amongst treatment groups over time. Different letters indicate a significant difference at $p<0.05$ amongst the treatment groups within a time-point. Asterisk ${ }^{*}$ ) denotes that the level in a treatment group differs between the two time-points. Results are presented as mean \pm SD of four wells, with ca. $10^{5}$ cells from 15 fish.

\subsection{Changes in the Gene Expression of Cytokine and Heat Shock Proteins in the Nasal Olfactory Leukocytes}

The expression of $i l 1 \beta$ increased significantly in PAA- and $\mathrm{H}_{2} \mathrm{O}_{2}$-exposed groups compared to controls $24 \mathrm{~h}$ after challenge, but such a change was no longer observed at $48 \mathrm{~h}$ (Figure $5 \mathrm{~A}$ ). On the other hand, AA exposure did not alter il1 $\beta$ expression at both time-points. Generally, il10 expression was not significantly affected by the oxidative chemical stressors, except in AA-exposed cells at $24 \mathrm{~h}$ post-challenge, where a significant downregulation was observed. The transcript level of il13r1a was significantly lower in PAA- and AA-exposed cells compared to control $24 \mathrm{~h}$ after challenge, though the change did not persist until $48 \mathrm{~h}$ (Figure 5C). The expression of ifn was unaltered in most treatment scenarios at both time-points (Figure 5D). 
A.

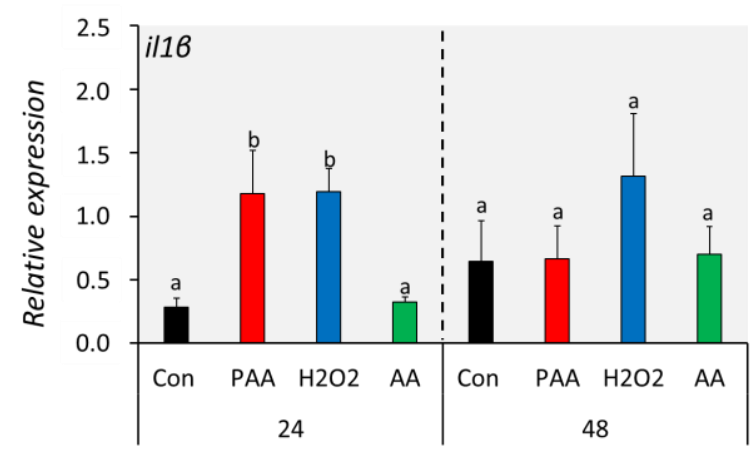

B.

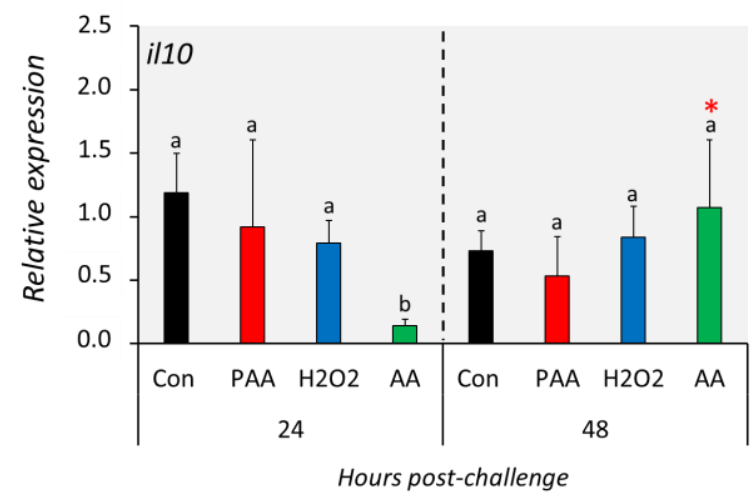

C.

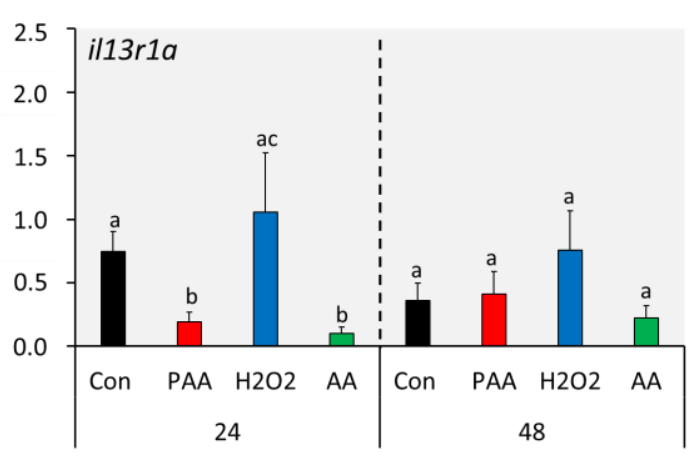

D.

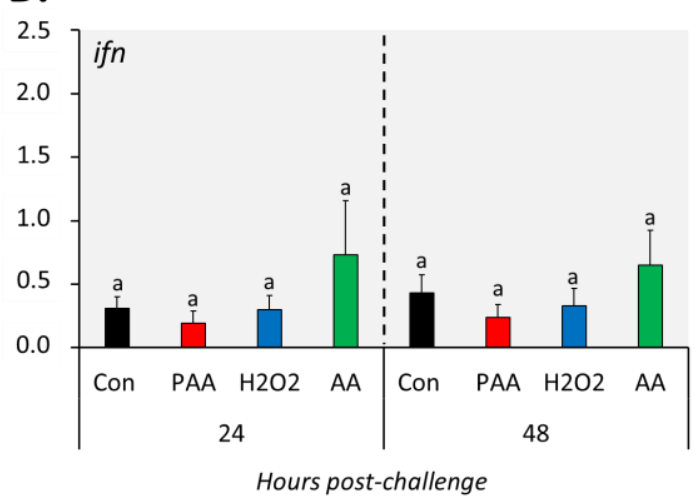

Figure 5. Changes in the expression of cytokine genes following exposure to oxidative chemical stressors (A-D). The transcript level of 4 selected genes (i.e., il1 $\beta$, il10, il13r1a, ifn) was quantified by RT-qPCR at 24 and $48 \mathrm{~h}$ after exposure to $100 \mu \mathrm{M}$ of PAA, $\mathrm{H}_{2} \mathrm{O}_{2}$, and AA for $30 \mathrm{~min}$. The control group was handled similarly, but without any chemical stimulation. For the explanation on statistics and notations, please refer to Figure 4.

The three chemical stressors did not significantly change the expression of $h s p 7024 \mathrm{~h}$ post-challenge (Figure 6A). After $48 \mathrm{~h}$, however, $h s p 70$ expression was significantly elevated in all treatment groups compared to control, and the highest increment was identified in $\mathrm{H}_{2} \mathrm{O}_{2}$-exposed cells. $\mathrm{Hsp} 90$ expression was not significantly altered in PAA- and $\mathrm{H}_{2} \mathrm{O}_{2}$-exposed cells at both time-points (Figure 6B). A significant downregulation was detected in AA-exposed cells at 24 but not at $48 \mathrm{~h}$ post-challenge, and the expression was higher in the latter than with the former time-point. 
A.

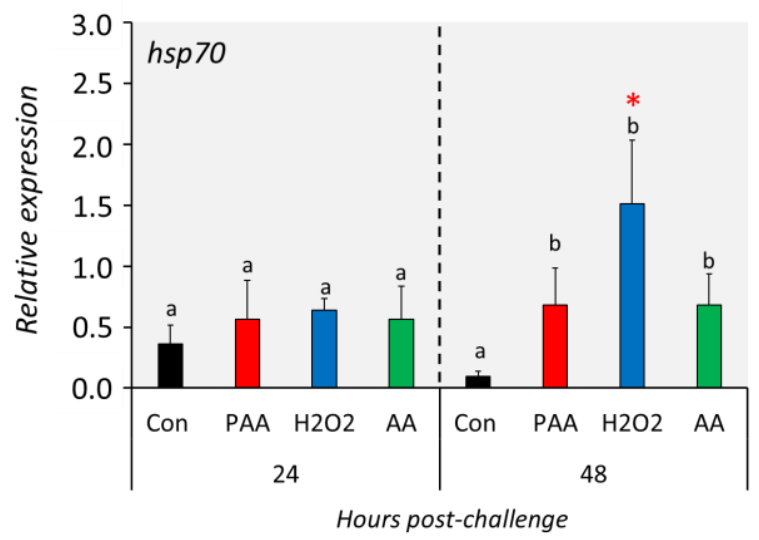

B.

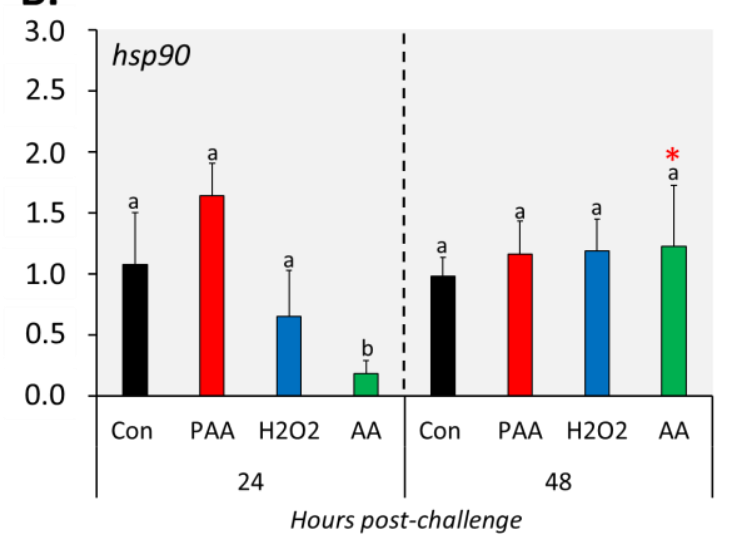

Figure 6. Changes in the expression of gene coding for heat shock proteins following oxidative chemical challenge (A,B). The transcript level of two selected genes (i.e., $h s p 70, h s p 90$ ) was quantified by RT-qPCR at 24 and $48 \mathrm{~h}$ after exposure to $100 \mu \mathrm{M}$ of PAA, $\mathrm{H}_{2} \mathrm{O}_{2}$, and AA for $30 \mathrm{~min}$. The control group was handled similarly, but without any chemical stimulation. For the explanation on statistics and notations, please refer to Figure 4.

\section{Discussion}

The present study reveals, through in vivo and in vitro exposure trials, how the nasal olfactory mucosa of Atlantic salmon mobilised its defence repertoires when challenged with oxidative chemical stressors. To our knowledge, this is the first report that demonstrates the molecular changes initiated by chemically induced oxidative stress in the nasal mucosa of a teleost fish. Using a nasal leukocyte model, it was further shown how the constituent oxidants of the tested therapeutics alter the cellular redox balance and the associated response mounted by a specific group of cells at the nasal olfactory mucosa to these challenges.

The two in vivo exposure studies uncovered the molecular repertoire of the nasal olfactory mucosa when challenged with either a periodic-low dose or less frequent-high dose of the oxidative agent PAA. In the first trial, we addressed the nasal consequences in the application of oxidant as a routine disinfectant in salmon. No conclusive implications can be drawn as to whether the exogenous oxidant was a stimulator or an inhibitor of nasal mucosal physiology as the ratios of upregulated and downregulated genes were equal after 45 days of exposure. However, two groups-haemoglobins and immune genes-displayed a trend in response to the exogenous oxidant. Haemoglobin $(\mathrm{Hb})$ is a predominant component in erythrocytes responsible for oxygen transport to the different tissues in vertebrates [31]. The $\mathrm{Hb}$ transcripts were upregulated in the nasal mucosa following periodic low-dose oxidant exposure, and both $\alpha$ and $\beta$ subunits were represented. In murine models, it has been demonstrated that overexpression of $\mathrm{Hb}$ affected a network of genes involved in $\mathrm{O}_{2}$ homeostasis, which subsequently resulted in the suppression of oxidative stress [32,33]. Exposing HepG2 cells to $\mathrm{H}_{2} \mathrm{O}_{2}$ induced the expression of both haemoglobin $\alpha$ and $\beta$, and their overexpression likewise resulted in cellular protection against oxidative stress [34]. The upregulation of several haemoglobin transcripts in response to periodic low-dose oxidant challenge was probably a protective mechanism of the nasal mucosa against oxidative stress. Despite the limited number, there was an indication that intermittent oxidant exposure may negatively regulate nasal immunity. The constitutive presence of oxidant in the environment may trigger several responses from an organism - continual mounting of protective action, accommodation, or habituation (i.e., decreasing response through time). It was reported earlier that periodic application of oxidant (i.e., PAA) in trout-a species closely related to salmon - somehow resulted in a dampening response, which could be indicative of habituation $[27,35]$. Such a consequence was likewise implicated in salmon post-smolts [28]. This partly sheds light on the downregulation of these immune genes after several weeks of exposure. We cannot disregard the potential oxidant-mediated immunosuppression in the nasal mucosa, as some of these transcripts 
have earlier been implicated in compromised immunity under oxidative stress in higher animal models [36,37].

Trial 2 provided a relatively clearer picture of how an oxidant administered at a higher dose, but less frequently, altered the nasal transcriptome as shown with a higher number of DEGs and a prominent regulatory profile. It was evident that oxidant treatment resulted in dysregulation of nasal redox balance, and hence triggered mucosal oxidative stress. In earlier publications, we have demonstrated that antioxidant defences in mucosal tissues (i.e., gills and skin) were remarkably altered by a similar oxidant though delivered at a much lower concentration $[4,7]$. The mobilisation of these antioxidant defences following oxidant exposure highlighted the capability of mucosal surfaces to muster physiological responses to increased environmental ROS, thereby protecting the mucosa from eventual oxidative damage, as supported by in vitro cell works demonstrated here as well. A substantial upregulation in immune-related genes was also observed, which likely offered insights into the complementarity of the immune and antioxidant defence mechanism at the mucosa during oxidative stress. There is a tight relationship between oxidative stress and immunity, and often the co-regulation of these two defence mechanisms provides robust responses during oxidative challenges $[3,38]$. One of the immune effector molecules that were markedly regulated was ornithine decarboxylase, a gene coding for an enzyme responsible for catalysing the conversion of ornithine to putrescine, the first and rate-limiting step in the synthesis of putrescine and the polyamines spermidine and spermine [39]. It is important to highlight that spermidine/spermine N1-acetyltransferase 1, a key molecule in amine metabolism, and with a counteractive function against oxidative stress, was significantly upregulated too. Increased expression of ornithine decarboxylase had been demonstrated in human hepatoma HUH7 cells subjected to chemically induced oxidative stress [40]. The upregulation observed in the present study is indicative of a similar function for protection against oxidative damage. Heat shock proteins play a role in several cellular processes that occur during and after exposure to oxidative stress [41]. There are indications, both in this trial as well as from previous studies using this oxidant, that it can induce transient oxidative stress $[4,7,27,28]$. The upregulation of both $h s p s$ in the nasal mucosa following oxidant exposure suggests intervention in oxidative stress-triggered changes by correction of conformation or selecting and directing aberrant proteins to the proteasome or lysosomes for degradation, in which these molecules are known to be key regulators. Besides the activation of several effector molecules that provide an interconnected response to oxidant-triggered oxidative stress, it is compelling to observe that several genes for molecules for cytostructural and extracellular matrix were represented in the list of upregulated genes. Previous studies using this oxidant found histostructural changes, though minimal, in the gill and skin mucosa $[4,27,42]$. We can speculate that the upregulation observed here may play a role in maintaining the structural integrity and barrier functionality under oxidative challenge. The upregulation of two genes responsible for extracellular matrix, GMP giant mucus protein and mucin $5 b$, implies that mucus physiology is affected by the oxidant and that the changes in these two genes underline their function in providing a layer of protective defence at the mucosa. Two related genes have been shown to participate in modulating the mucus layer of the olfactory epithelium in mammalian models [43,44], and they likely exert a similar function in the nasal mucosa of salmon. However, this must be functionally ascertained in the future. DEGs with known functions in lipid metabolism were downregulated in the oxidant-challenged nasal mucosa. Though it is difficult to conclude whether oxidative stress triggered an imbalanced lipid metabolism in the nasal mucosa because of a limited panel of DEGs under this category, it is interesting to note that such interaction has been reported in other animals $[45,46]$. The downregulation observed in these lipid metabolic mediators indicates that oxidant exposure may interfere with this process, though the magnitude remains an open question.

We then focused on one specific cell type at the nasal mucosa to investigate how the cells respond to the oxidant, as well as to the two other constituents of PAA trade products. The proliferation of nasal olfactory leukocytes was affected by the three chemical stressors $24 \mathrm{~h}$ after exposure at an almost similar rate. However, such an influence was no longer observable $48 \mathrm{~h}$ after exposure in 
PAA- and $\mathrm{H}_{2} \mathrm{O}_{2}$-exposed cells. This indicates that the effects on cellular proliferation following PAA and $\mathrm{H}_{2} \mathrm{O}_{2}$ stimulation could be transitory, and the cells were able to recover quickly. AA was more potent in inhibiting cellular proliferation, as the effects persisted until $48 \mathrm{~h}$. Nasal olfactory leukocytes exhibited migratory potential, as all factors resulted in migration of the cells, though at varying levels. Cell migration plays an important role in many normal biological and pathophysiological processes, and oxidants can either promote or inhibit migration [47]. $\mathrm{H}_{2} \mathrm{O}_{2}$ administered individually and not in mixture with PAA and AA modulated the migration of the nasal olfactory leukocytes, suggesting its potent chemoattractant function, as demonstrated by earlier studies in other animal models $[47,48]$. The migratory potential of nasal olfactory leukocytes is vital in orchestrating a cellular response when environmental ROS levels reach a concerning concentration or when pathophysiological response had been caused by oxidative stress.

We further asked: If the oxidants triggered changes in the cellular phenotypic response (i.e., proliferation and migration), can they also induce oxidative stress? The oxidant used had been shown to prompt oxidative stress at the systemic [7] and tissue [4,7] levels, but this has yet to be demonstrated at the cellular level. Exposure to the three chemical oxidative stressors resulted in an increase in the intracellular concentration of ROS, which indicates that it induced redox imbalance; hence, oxidative stress occurred. Both $\mathrm{H}_{2} \mathrm{O}_{2}$ and AA have long been identified as inducers of oxidative stress [11,48,49]. Here, we have shown that PAA and $\mathrm{H}_{2} \mathrm{O}_{2}$ were far more potent inducers of intracellular ROS production than AA in nasal leukocytes. Interestingly, for both PAA and AA, induction of intracellular level was transient because, after an elevated level $24 \mathrm{~h}$ after exposure, the concentration returned to the normal/control level. This was not observed in $\mathrm{H}_{2} \mathrm{O}_{2}$-exposed cells; their intracellular ROS was still at an elevated level $48 \mathrm{~h}$ after exposure, though the level was slightly lower compared to that at $24 \mathrm{~h}$. This indicates that cells exposed to PAA and AA have a faster capability to abate an increased intracellular ROS level than $\mathrm{H}_{2} \mathrm{O}_{2}$-exposed cells, which further suggests that $\mathrm{H}_{2} \mathrm{O}_{2}$ has a higher and more persisting impact as an oxidative stressor on the nasal leukocytes. Different oxidants could trigger different mechanisms of oxidative stress induction [1,50], and somehow the observations in the present study are in agreement with this differential regulatory impact.

The increased intracellular ROS incited by the three chemical stressors initiated a response from the antioxidant system of the nasal olfactory leukocytes. The expression of enzymatic antioxidants was predominantly upregulated, indicating their key role towards the threats of the oxidative stressors. The overall expression profile of these antioxidant genes shows that PAA and $\mathrm{H}_{2} \mathrm{O}_{2}$ were more potent triggers than AA, which, to some extent, is in agreement with the results in terms of how the oxidative stressors affected the intracellular ROS level. Antioxidant markers $g p x, g r, g s t a$, and cat were perhaps the key response molecules, as their expression was significantly elevated in at least one time-point in PAA- and $\mathrm{H}_{2} \mathrm{O}_{2}$-exposed cells. The response profile can be divided into two arbitrary groups based on their elevated temporal expression - early (i.e., $g r$ ) and late (i.e., gsta and cat) oxidant responders. Glutathione peroxidase metabolises $\mathrm{H}_{2} \mathrm{O}_{2}$ to $\mathrm{H}_{2} \mathrm{O}$, and the reduced glutathione provides an antioxidant function by resetting the redox status in tissues [51]. Gpx has been implicated in the responses of fish to environmental toxicants that can trigger oxidative stress [52], and this mechanism may also be working in nasal leukocytes. We have previously documented oxidant-induced alteration in gpx expression in the gills and skin of salmon; hence, the results provide further evidence that it is a vital molecule for the mucosal antioxidant system in this fish species [7]. It is interesting to note that glutathione reductase gr was upregulated both in the cells and as one of the DEGs identified in Trial 2. Gr, as an antioxidant, is responsible for the regeneration of reduced glutathione during detoxification of peroxides and free radicals formed in mitochondria, thus maintaining the redox potential of the cell [53]. The upregulation of $g r$ in both instances, as well as in previous oxidant studies in salmon $[7,10]$, provides strong support for its canonical function in mucosal antioxidant defence, that is likely ubiquitously regulated by the oxidative chemical stressor. There was no apparent tendency for AA-induced changes in the antioxidant repertoire in the nasal olfactory leukocytes, though both $g p x$ and $c u / z n$ sod were responsive. 
The overall profile in the expression of cytokine markers and heat shock protein genes could not be conclusively established, though the stochastic changes provide insights into how oxidative stressors may likely influence these molecules. The relationship between oxidants and inflammatory response is well-established in mammalian systems [54], though such interaction is less understood in fish, especially concerning exogenous oxidative stressors. We have shown that $i l 1 b$ expression was modulated by PAA and $\mathrm{H}_{2} \mathrm{O}_{2} 24 \mathrm{~h}$ after exposure. An earlier publication reported that increased IL-1 $\beta$ stimulated glutathione production, thereby protecting neurons from oxidative damage [55]. The present data could not decisively ascertain whether such a directional effect was also initiated in the nasal leukocytes; however, the upregulation of $i l 1 b$ and the two genes of glutathione metabolism offer a potential link. In Trial 2, we have identified several cytokines genes that were upregulated following the oxidant challenge. It is possible that this increase in expression facilitated the migration of inflammatory cells to the epithelial surface where the oxidant was in close contact. One of the areas that must be explored in the future is the early phase of the inflammatory response, which was not captured by the current data. Both $h s p 70$ and $h s p 90$ were significantly upregulated in the olfactory rosette in Trial 2, but a similar change in the cell experiment could not be observed. The mode of oxidant application may play in part in this apparent difference.

\section{Conclusions}

Fish encounter environmental oxidants during production, as several husbandry practices rely on the use of oxidative chemical compounds, such as during water disinfection [27] or disease treatment [9]. Application frequency may vary, from continuous to periodic, each depending on its intended use (i.e., disinfectant vs. therapy). PAA is a potent oxidant, though the window of safe dose is limited [56]. The present study contributes to a better understanding of how the nasal olfactory mucosa of Atlantic salmon, one of the least explored mucosal tissues with regards to redox physiology, mount physiological and immunological responses when prompted with exogenously generated oxidative challenges. Oxidative stress is a physiological imbalance that requires a coordinated response to protect the organism from oxidative damage and, eventually, facilitate repair and recovery. The nasal mucosa of salmon can activate different molecules that may likely participate in the adaptive responses to oxidative stress. Nasal immunology is one of the emerging fields in fish immunology research [20], and the several oxidant-responsive genes identified in the paper are potential molecules for in-depth functional characterisation for their role in the nasal microenvironment, mainly towards non-infectious agents. One area that is interesting for future experiment is on whether exogenous antioxidants (e.g., in-feed antioxidants) can mitigate the effects of the chemical oxidative stressors by augmenting the innate antioxidant system of fish.

Supplementary Materials: The following are available online at http:/www.mdpi.com/2076-3921/9/11/1144/s1, Supplementary File 1. List of primers used in qPCR analysis. Supplementary File 2. List of differentially expressed genes identified in Trials 1,2 .

Author Contributions: C.C.L. conceived the research idea. C.C.L. and M.W.B. designed the in vivo fish trial. C.C.L., J.O. and M.W.B. performed the in vivo fish trial. C.C.L., J.O. and M.W.B. collected the samples. C.C.L. and V.V. performed the cell experiment. C.C.L., J.O., V.V. and M.H.S.H. conducted the lab analyses. M.H.S.H. and A.K. performed the microarray. C.C.L. and A.K. handled and processed the data. All authors contributed to the writing and review of the final version of the manuscript. All authors have read and agreed to the published version of the manuscript.

Funding: The study was funded by grants from the Research Council of Norway (237856 and 194050) and the Norwegian Seafood Research Fund (901472).

Acknowledgments: J. Osorio wishes to acknowledge the ERASMUS+ Student Mobility Programme for financing his 5-month research stay at Nofima. Lars-Flemming Pedersen of DTU Aqua is thanked for his insights on the trial conducted at HiT. The assistance of the technical staff at NCRA (Britt-Kristin Megård Reiten, Bernhard Eckel, Yuriy Marchenko, Jascha Gerwins) and HiT (Mads Korfitz Mortensen) during the fish trials is also acknowledged. We would like to thank Fiskefjøset at NMBU for providing the fish used in the cell experiment and Lisbeth Rørmark of Lilleborg AS for the PAA product. We would like to acknowledge the 4 independent reviewers for their comments and suggestions that significantly improved the scientific value of this paper. 
Conflicts of Interest: The authors declare no competing interests. Mention of trade names in this manuscript does not imply any recommendation or endorsement by Nofima or the University of Lisbon.

\section{References}

1. Birben, E.; Sahiner, U.M.; Sackesen, C.; Erzurum, S.; Kalayci, O. Oxidative stress and antioxidant defense. World Allergy Organ. J. 2012, 5, 9-19. [CrossRef]

2. Lackner, R. "Oxidative stress" in fish by environmental pollutants. In Fish Ecotoxicology; Braunbeck, T., Hinton, D.E., Streit, B., Eds.; Birkhäuser: Basel, Switzerland, 1998; pp. 203-224. [CrossRef]

3. Biller, J.D.; Takahashi, L.S. Oxidative stress and fish immune system: Phagocytosis and leukocyte respiratory burst activity. An. Acad. Bras. Ciênc. 2018, 90,3403-3414. [CrossRef]

4. Lazado, C.C.; Sveen, L.R.; Soleng, M.; Pedersen, L.-F.; Timmerhaus, G. Crowding reshapes the mucosal but not the systemic response repertoires of Atlantic salmon to peracetic acid. Aquaculture 2020, 531, 735830. [CrossRef]

5. Miller, J.K.; Brzezinska-Slebodzinska, E.; Madsen, F.C. Oxidative stress, antioxidants, and animal function. J. Dairy Sci. 1993, 76, 2812-2823. [CrossRef]

6. Yoneyama, M.; Kawada, K.; Gotoh, Y.; Shiba, T.; Ogita, K. Endogenous reactive oxygen species are essential for proliferation of neural stem/progenitor cells. Neurochem. Int. 2010, 56, 740-746. [CrossRef] [PubMed]

7. Soleng, M.; Johansen, L.-H.; Johnsen, H.; Johansson, G.S.; Breiland, M.W.; Rørmark, L.; Pittman, K.; Pedersen, L.-F.; Lazado, C.C. Atlantic salmon (Salmo salar) mounts systemic and mucosal stress responses to peracetic acid. Fish Shellfish Immunol. 2019, 93, 895-903. [CrossRef] [PubMed]

8. Spiliotopoulou, A.; Rojas-Tirado, P.; Chhetri, R.K.; Kaarsholm, K.M.S.; Martin, R.; Pedersen, P.B.; Pedersen, L.-F.; Andersen, H.R. Ozonation control and effects of ozone on water quality in recirculating aquaculture systems. Water Res. 2018, 133, 289-298. [CrossRef] [PubMed]

9. Bechmann, R.K.; Arnberg, M.; Gomiero, A.; Westerlund, S.; Lyng, E.; Berry, M.; Agustsson, T.; Jager, T.; Burridge, L.E. Gill damage and delayed mortality of Northern shrimp (Pandalus borealis) after short time exposure to anti-parasitic veterinary medicine containing hydrogen peroxide. Ecotoxicol. Environ. Saf. 2019, 180, 473-482. [CrossRef] [PubMed]

10. Stiller, K.T.; Kolarevic, J.; Lazado, C.C.; Gerwins, J.; Good, C.; Summerfelt, S.T.; Mota, V.C.; Espmark, Å.M. The effects of ozone on Atlantic salmon post-smolt in brackish water-Establishing welfare indicators and thresholds. Int. J. Mol. Sci. 2020, 21, 5109. [CrossRef] [PubMed]

11. Vera, L.M.; Migaud, H. Hydrogen peroxide treatment in Atlantic salmon induces stress and detoxification response in a daily manner. Chronobiol. Int. 2016, 33, 530-542. [CrossRef] [PubMed]

12. Vatansever, F.; de Melo, W.C.M.A.; Avci, P.; Vecchio, D.; Sadasivam, M.; Gupta, A.; Chandran, R.; Karimi, M.; Parizotto, N.A.; Yin, R.; et al. Antimicrobial strategies centered around reactive oxygen species-Bactericidal antibiotics, photodynamic therapy, and beyond. FEMS Microbiol. Rev. 2013, 37, 955-989. [CrossRef] [PubMed]

13. Cabillon, N.A.R.; Lazado, C.C. Mucosal barrier functions of fish under changing environmental conditions. Fishes 2019, 4, 2. [CrossRef]

14. Sepahi, A.; Casadei, E.; Tacchi, L.; Muñoz, P.; LaPatra, S.E.; Salinas, I. Tissue microenvironments in the nasal epithelium of rainbow trout (Oncorhynchus mykiss) define two distinct CD8 $\alpha^{+}$cell populations and establish regional immunity. J. Immunol. 2016, 197, 4453-4463. [CrossRef] [PubMed]

15. Peatman, E.; Beck, B.H. 1-Why mucosal health? In Mucosal Health in Aquaculture; Beck, B.H., Peatman, E., Eds.; Academic Press: San Diego, CA, USA, 2015; pp. 1-2. [CrossRef]

16. Tacchi, L.; Musharrafieh, R.; Larragoite, E.T.; Crossey, K.; Erhardt, E.B.; Martin, S.A.M.; LaPatra, S.E.; Salinas, I. Nasal immunity is an ancient arm of the mucosal immune system of vertebrates. Nat. Commun. 2014, 5, 5205. [CrossRef]

17. Døving, K.B. Functional properties of the fish olfactory system. In Progress in Sensory Physiology 6; Autrum, H., Ottoson, D., Perl, E.R., Schmidt, R.F., Shimazu, H., Willis, W.D., Eds.; Springer: Berlin/Heidelberg, Germany, 1986; pp. 39-104. [CrossRef]

18. Sepahi, A.; Kraus, A.; Casadei, E.; Johnston, C.A.; Galindo-Villegas, J.; Kelly, C.; García-Moreno, D.; Muñoz, P.; Mulero, V.; Huertas, M.; et al. Olfactory sensory neurons mediate ultrarapid antiviral immune responses in a TrkA-dependent manner. Proc. Natl. Acad. Sci. USA 2019, 116, 12428-12436. [CrossRef] [PubMed] 
19. Das, P.K.; Salinas, I. Fish nasal immunity: From mucosal vaccines to neuroimmunology. Fish Shellfish Immunol. 2020, 104, 165-171. [CrossRef] [PubMed]

20. Sepahi, A.; Salinas, I. The evolution of nasal immune systems in vertebrates. Mol. Immunol 2016, 69, 131-138. [CrossRef]

21. Hansen, A.; Zielinski, B.S. Diversity in the olfactory epithelium of bony fishes: Development, lamellar arrangement, sensory neuron cell types and transduction components. J. Neurocytol. 2005, 34, 183-208. [CrossRef]

22. Zhang, Y.-A.; Salinas, I.; Li, J.; Parra, D.; Bjork, S.; Xu, Z.; LaPatra, S.E.; Bartholomew, J.; Sunyer, J.O. IgT, a primitive immunoglobulin class specialised in mucosal immunity. Nat. Immunol. 2010, 11, 827-835. [CrossRef]

23. Pace, E.; Ferraro, M.; Di Vincenzo, S.; Gerbino, S.; Bruno, A.; Lanata, L.; Gjomarkaj, M. Oxidative stress and innate immunity responses in cigarette smoke stimulated nasal epithelial cells. Toxicol. In Vitro 2014, 28, 292-299. [CrossRef]

24. Dokic, D.; Trajkovska-Dokic, E.; Howarth, H.P. Effects of ozone on nasal mucosa (endothelial cells). Prilozi 2011, 32, 87-99.

25. Wagner, J.G.; Hotchkiss, J.A.; Harkema, J.R. Enhancement of nasal inflammatory and epithelial responses after ozone and allergen coexposure in brown norway rats. Toxicol. Sci. 2002, 67, 284-294. [CrossRef]

26. Pedersen, L.F.; Lazado, C.C. Decay of peracetic acid in seawater and implications for its chemotherapeutic potential in aquaculture. Aquac. Environ. Interact. 2020, 12, 153-165. [CrossRef]

27. Liu, D.; Lazado, C.C.; Pedersen, L.-F.; Straus, D.L.; Meinelt, T. Antioxidative, histological and immunological responses of rainbow trout after periodic and continuous exposures to a peracetic acid-based disinfectant. Aquaculture 2020, 520, 734956. [CrossRef]

28. Lazado, C.C.; Pedersen, L.-F.; Kirste, K.H.; Soleng, M.; Breiland, M.W.; Timmerhaus, G. Oxidant-induced modifications in the mucosal transcriptome and circulating metabolome of Atlantic salmon. Aquat. Toxicol. 2020, 227, 105625. [CrossRef]

29. Nagasawa, K.; Lazado, C.; Fernandes, J.M. Validation of endogenous reference genes for qPCR quantification of muscle transcripts in Atlantic cod subjected to different photoperiod regimes. In Aquaculture; IntechOpen: London, UK, 2012.

30. Krasnov, A.; Timmerhaus, G.; Afanasyev, S.; Jørgensen, S.M. Development and assessment of oligonucleotide microarrays for Atlantic salmon (Salmo salar L.). Comp. Biochem. Physiol. Part D 2011, 6, 31-38. [CrossRef] [PubMed]

31. Quinn, N.L.; Boroevich, K.A.; Lubieniecki, K.P.; Chow, W.; Davidson, E.A.; Phillips, R.B.; Koop, B.F.; Davidson, W.S. Genomic organisation and evolution of the Atlantic salmon hemoglobin repertoire. BMC Genom. 2010, 11, 539. [CrossRef] [PubMed]

32. Biagioli, M.; Pinto, M.; Cesselli, D.; Zaninello, M.; Lazarevic, D.; Roncaglia, P.; Simone, R.; Vlachouli, C.; Plessy, C.; Bertin, N.; et al. Unexpected expression of alpha- and beta-globin in mesencephalic dopaminergic neurons and glial cells. Proc. Natl. Acad. Sci. USA 2009, 106, 15454-15459. [CrossRef]

33. Nishi, H.; Inagi, R.; Kato, H.; Tanemoto, M.; Kojima, I.; Son, D.; Fujita, T.; Nangaku, M. Hemoglobin is expressed by mesangial cells and reduces oxidant stress. J. Am. Soc. Nephrol. 2008, 19, 1500-1508. [CrossRef]

34. Liu, W.; Baker, S.S.; Baker, R.D.; Nowak, N.J.; Zhu, L. Upregulation of hemoglobin expression by oxidative stress in hepatocytes and its implication in nonalcoholic steatohepatitis. PLoS ONE 2011, 6, e24363. [CrossRef]

35. Liu, D.; Pedersen, L.-F.; Straus, D.L.; Kloas, W.; Meinelt, T. Alternative prophylaxis/disinfection in aquaculture-Adaptable stress induced by peracetic acid at low concentration and its application strategy in RAS. Aquaculture 2017, 474, 82-85. [CrossRef]

36. Tran, H.B.; Ahern, J.; Hodge, G.; Holt, P.; Dean, M.M.; Reynolds, P.N.; Hodge, S. Oxidative stress decreases functional airway mannose binding lectin in COPD. PLoS ONE 2014, 9, e98571. [CrossRef] [PubMed]

37. Kawashima, R.; Shimizu, T.; To, M.; Saruta, J.; Jinbu, Y.; Kusama, M.; Tsukinoki, K. Effects of stress on mouse $\beta$-defensin-3 expression in the upper digestive mucosa. Yonsei Med. J. 2014, 55, 387-394. [CrossRef] [PubMed]

38. Biller-Takahashi, J.D.; Takahashi, L.S.; Mingatto, F.E.; Urbinati, E.C. The immune system is limited by oxidative stress: Dietary selenium promotes optimal antioxidative status and greatest immune defense in pacu Piaractus mesopotamicus. Fish Shellfish Immunol. 2015, 47, 360-367. [CrossRef] 
39. Bacchi, C.; Nathan, H.; Hutner, S.; McCann, P.; Sjoerdsma, A. Polyamine metabolism: A potential therapeutic target in trypanosomes. Science 1980, 210, 332-334. [CrossRef]

40. Smirnova, O.A.; Isaguliants, M.G.; Hyvonen, M.T.; Keinanen, T.A.; Tunitskaya, V.L.; Vepsalainen, J.; Alhonen, L.; Kochetkov, S.N.; Ivanov, A.V. Chemically induced oxidative stress increases polyamine levels by activating the transcription of ornithine decarboxylase and spermidine/spermine-N1-acetyltransferase in human hepatoma HUH7 cells. Biochimie 2012, 94, 1876-1883. [CrossRef] [PubMed]

41. Kalmar, B.; Greensmith, L. Induction of heat shock proteins for protection against oxidative stress. Adv. Drug Deliv. Rev. 2009, 61, 310-318. [CrossRef]

42. Lazado, C.C.; Haddeland, S.; Timmerhaus, G.; Berg, R.S.; Merkin, G.; Pittman, K.; Pedersen, L.-F. Morphomolecular alterations in the skin mucosa of Atlantic salmon (Salmo salar) after exposure to peracetic acid-based disinfectant. Aquac. Rep. 2020, 17, 100368. [CrossRef]

43. Débat, H.; Eloit, C.; Blon, F.; Sarazin, B.; Henry, C.; Huet, J.-C.; Trotier, D.; Pernollet, J.-C. Identification of Human Olfactory Cleft Mucus Proteins Using Proteomic Analysis. J. Proteome Res. 2007, 6, 1985-1996. [CrossRef]

44. Kennel, C.; Gould, E.A.; Larson, E.D.; Salcedo, E.; Vickery, T.; Restrepo, D.; Ramakrishnan, V.R. Differential expression of mucins in murine olfactory versus respiratory epithelium. Chem. Senses 2019, 44, 511-521. [CrossRef]

45. Chen, Q.; Tang, L.; Xin, G.; Li, S.; Ma, L.; Xu, Y.; Zhuang, M.; Xiong, Q.; Wei, Z.; Xing, Z.; et al. Oxidative stress mediated by lipid metabolism contributes to high glucose-induced senescence in retinal pigment epithelium. Free Radic. Biol. Med. 2019, 130, 48-58. [CrossRef] [PubMed]

46. Seo, E.; Kang, H.; Choi, H.; Choi, W.; Jun, H.-S. Reactive oxygen species-induced changes in glucose and lipid metabolism contribute to the accumulation of cholesterol in the liver during aging. Aging Cell 2019, 18, e12895. [CrossRef] [PubMed]

47. Hurd, T.R.; DeGennaro, M.; Lehmann, R. Redox regulation of cell migration and adhesion. Trends Cell Biol. 2012, 22, 107-115. [CrossRef] [PubMed]

48. Klyubin, I.; Kirpichnikova, K.; Gamaley, I. Hydrogen peroxide-induced chemotaxis of mouse peritoneal neutrophils. Eur. J. Cell Biol. 1996, 70, 347-351. [PubMed]

49. Terasaki, M.; Ito, H.; Kurokawa, H.; Tamura, M.; Okabe, S.; Matsui, H.; Hyodo, I. Acetic acid is an oxidative stressor in gastric cancer cells. J. Clin. Biochem. Nutr. 2018, 63, 36-41. [CrossRef]

50. Costantini, D. Understanding diversity in oxidative status and oxidative stress: The opportunities and challenges ahead. J. Exp. Biol. 2019, 222, jeb194688. [CrossRef]

51. Parihar, M.S.; Javeri, T.; Hemnani, T.; Dubey, A.K.; Prakash, P. Responses of superoxide dismutase, glutathione peroxidase and reduced glutathione antioxidant defenses in gills of the freshwater catfish (Heteropneustes fossilis) to short-term elevated temperature. J. Therm. Biol. 1997, 22, 151-156. [CrossRef]

52. Sukhovskaya, I.V.; Borvinskaya, E.V.; Smirnov, L.P.; Kochneva, A.A. Role of glutathione in functioning of the system of antioxidant protection in fish (review). Inland Water Biol. 2017, 10, 97-102. [CrossRef]

53. Čolak, E.; Žorić, L. 6-Antioxidants and Age-related macular degeneration. In Handbook of Nutrition, Diet, and the Eye, 2nd ed.; Preedy, V.R., Watson, R.R., Eds.; Academic Press: Cambridge, MA, USA, 2019; pp. 85-106. [CrossRef]

54. Lugrin, J.; Rosenblatt-Velin, N.; Parapanov, R.; Liaudet, L. The role of oxidative stress during inflammatory processes. Biol. Chem. 2013, 395, 241. [CrossRef]

55. Chowdhury, T.; Allen, M.F.; Thorn, T.L.; He, Y.; Hewett, S.J. Interleukin-1 $\beta$ protects neurons against oxidant-induced injury via the promotion of astrocyte glutathione production. Antioxidants 2018, 7, 100. [CrossRef]

56. Acosta, F.; Montero, D.; Izquierdo, M.; Galindo-Villegas, J. High-level biocidal products effectively eradicate pathogenic $\gamma$-proteobacteria biofilms from aquaculture facilities. Aquaculture 2021, 532, 736004. [CrossRef]

Publisher's Note: MDPI stays neutral with regard to jurisdictional claims in published maps and institutional affiliations. 